\title{
Global Dimensions of Organized Crime and Ways of Preventing Threats at International Level
}

\section{Nika Chitadze}

Black Sea Region Geopolitical Research Center, www.centers.ibsu.edu.ge/index.php/en/home-cbsg International Black Sea University, Tbilisi, Georgia, https://www.ibsu.edu.ge/en

\begin{abstract}
The present paper predominantly focuses on the different approaches related to the definition of organized crime, the primary conditions that create a convenient foundation upon which organized crime can develop, the main activities of organized criminal groups, and leading organized criminal formations across the different regions of the world, in particular, the Italian Mafia, the Japanese bōryokudan (Yakuza), Chinese triads, Colombian drug cartels, Russian criminal organizations ("Russian Mafia"), and so on.

The second part of the paper is dedicated to the review of the international experience of fighting against transnational organized crime, particularly with regard to different international conventions and agreements within the nineteenth century and first half of the twentieth century. It also explores this phenomenon on a UN-level and with reference to a range of European institutions (the EU, Council of Europe). The concluding section sees an examination of the role of law enforcement agencies in the fight against organized crime.
\end{abstract}

Keywords: Organized crime, smuggling, corruption, mafia, illegal formations, international conventions, law enforcement agencies.

\section{Introduction}

Organized crime is namely the form of criminality characterized by steady activity perpetrated by criminal organizations (organized groups and criminal associations) with a hierarchic structure, a material and financial base and connections to state structures, which exploit corruption mechanisms. The primary reasons for the development of organized crime include the following pro- 
cesses: the intertwining of leaders and active participants in organized criminal formations with representatives of the legislative, executive and judicial branches of the state, business, commerce, mass media and culture; the incapacity of the state to protect a number of basic constitutional rights and the interests of citizens and society; the cultivation of the ideas of the market and of private property without the proper legal guarantees; the unjustified delay in the adoption of basic laws ensuring normal passage to market, primarily related to the combat of organized crime and corruption; impoverishment and the legal nihilism of the majority of the population of the country; the lobbying for the interests of separate groups by the officials responsible for financial gain. The conditions of criminality are the sum total of the phenomena which by themselves cannot create criminality, but which serve as the circumstances that facilitate its appearance and existence. The conditions of criminality are subdivided into three basic groups:

1. The associated conditions: those which form the general background of events and phenomena, the circumstances of place and time;

2. The necessary conditions without which an event could not be initiated;

3. The appropriate conditions: the set of all necessary conditions.

The objective conditions of crime include deficiencies in the organizational, legal, and technical orders, which support and, on occasion, revive the subjective and objective reasons for crimes. The subjective conditions of criminality are the roles played by demographics and social class and psychological quirks within the population. The division of the reasons and conditions of criminality into objective and subjective makes it possible to determine the potential outcomes of the influence of external factors on human behavior and the influence of internal, personal, unique elements on an individual's behavior. Reasons and conditions are closely interconnected, and both are necessary for criminality to surface. Those factors designated as reasons cannot create the appropriate conditions for criminality without these very conditions. The connection between reasons and conditions is called "determinism." Specifically, the interaction of reasons and conditions generates consequence.

\section{Approaches to Defining Organized Crime}

Attempting to define organized crime is a complex task, matching the complexity of organized crime itself. As a result, there are many different approaches to pinning down the base elements of organized crime in terms of normative and doctrinal definitions. This multiplicity of definitions derives from the fact that not one formulation can contain within it the entire range of forms of organized criminality, and take into account the economic, regional and ethic differences that exist.

The first attempts to define "organized criminality" as a concept in the USA were made by David L. Herbert and Howard Tritt in the 1950s and 60s, when 
the committees of Congress began to reveal the proofs of existence of secret criminal society or cartel by the name of "the Mafia" or "Cosa Nostra."

The 1965 and 1966 Oyster Bay Conferences were dedicated to the issue of combating organized crime, and, as part of this, formulated the following definition: "Organized crime is the product of a self-perpetuating criminal conspiracy to wring exorbitant profits from our society by any means - fair and foul, legal and illegal. Despite personnel changes, the conspiratorial entity continues." ${ }^{2}$

The US Omnibus Crime Control and Safe Streets Act of 1968 provides another definition:

'Organized crime' means the unlawful activities of the members of a highly organized, disciplined association engaged in supplying illegal goods and services, including but not limited to gambling, prostitution, loan sharking, narcotics, labor racketeering, and other unlawful activities of members of such organizations. ${ }^{3}$

The FBI defines an organized criminal group as any group of persons which has a specific formalized structure, the basic purpose of which is obtaining an income through illegal activity, which supports its position through the use of violence and threats, involving state officials in corruption, bribery or extortion, and usually has influence on the people who live in the territory in question or even the country as a whole. ${ }^{4}$

\section{Organized Criminal Formations}

Organized criminal formations differ from each other in having geographically and nationally specific elements to their character. They are also differentiated from one another according to the degree of globalization: they can act within the limits of one city, within one country or even cross the borders of individual states, becoming transnational. The list of criminal organizations on the global level, which are active in a large number of countries and regions across the world, includes: the Italian Mafia, the Japanese bōryokudan (Yakuza), Chinese triads, Colombian drug cartels; and, recently having breached national boundaries, Russian criminal organizations ("the Russian Mafia"). It is worth noting that the term "organized criminal formations," as referred to in the literature, covers two types of collective criminal groups:

1 David L. Herbert and Howard Tritt, Corporations of Corruption. A Systematic Study of Organized Crime (Springfield, IL: Charles C. Thomas, 1984).

2 "Definitions of Organized Crime," collected by Klaus von Lampe, Oyster Bay Conferences, www.organized-crime.de/organizedcrimedefinitions.htm\#oyster.

3 Public Law 90-351, Title I, Part F (b), cf. Kristin M. Finklea, Organized Crime in the United States: Trends and Issues for Congress (Washington, DC: Congressional Research Service, 2010), 3.

4 "Definitions of Organized Crime," collected by Klaus von Lampe, www.organizedcrime.de/OCDEF1.htm. 
- Criminal organization - all forms of the associations of people directly involved in the commitment of crime, conducting criminal activity: organized criminal groups, gangs, illegal armed formations and so forth;

- Criminal community (association) - a form which first unites organizations themselves, and which organizes, coordinates and guides their activity in turn to protect the interests of the criminal association; it can also fulfill the function of a "criminal trade union," ensuring the social protection of its members. As a rule, such associations are not directly involved in criminal activities, passing these on to smaller organizations under their influence.

Several experts and authors also consider it possible to isolate several types or levels of criminal formations. For example, some specialists separate criminal formations into three such levels: ${ }^{5}$

- Organized groups, driven by committing common crimes (robberies, theft) and not in possession of fixed corruption links;

- Criminal groups, in which the participants fulfill strictly defined roles, but the basic source of means of which is not the committing of common crimes, but rather acts connected with the violation of routine economic activity or the illegal circulation of specific goods (weapon, narcotic drugs);

- Criminal associations, which unite several criminal groups.

In this case, several authors split organized criminality into two, or even three, levels. It is also possible to use other methods of classification. The UN separates the traditional type of criminal organization, namely the mafia family, in which there is a hierarchy and rules of behavior, from the newer type of criminal association in which members are united under a professional sign, where the organization is brought together thanks to the carrying out of criminal activity of a specific form, and hierarchical and normative connections are expressed less; ethnic, cultural, and historical connections can also serve as the uniting factor. ${ }^{6}$

\section{Activity of Criminal Organizations}

The activity of criminal organizations can be divided into several models:

- Accomplishing different activities targeted towards the completion of one serious crime, complex in its mechanism (for example, an act of terrorism);

5 A.I. Dolgovaya, ed., Criminology: University Textbook, $3^{\text {rd }}$ edition (Moscow: Norma, 2005), pp. 508-509. - in Russian.

6 G.I. Bogush et al., Criminology: Tutorial, ed. N.F. Kuznetsova (Moscow, 2007), 188189. - in Russian. 
- Systematically committing different crimes with the goal of attaining a particular objective: obtaining money, victory in the elections into public office and so forth;

- Systematically committing a uniform type of crime which acts as a constant form of activity and the basic source of income for the group (professional criminal activity).

The activity of large criminal associations has a specific character: they are structurally divided into sub-units: analytical, reconnaissance and counterintelligence, transport, judicial and so forth.

One additional unique character of the activity of such organizations is the interpenetration of criminal and legal activity: they are frequently engaged in legitimate business activity, in charitable acts (with the purpose of the creation of a positive image from a citizen's point of view), in developing close economic ties with the business world, in guarding enterprises and judicial organizations.

The interaction between associations of this nature and smaller criminal organizations takes the form of an exchange of information, conducting meetings to discuss internal and external conflicts, the organization of networking, the division of spheres of influence, the development of coordinated measures to resist the actions of law enforcement agencies, and the establishment of control over the activity of organs of state.

\section{The Signs of Organized Criminal Formations}

In order to define a criminal formation, it must possess fixed characteristics. Some experts separate out the characteristics which appear in all or practically all organized criminal formations. These can be further sub-divided into facultative elements, and include:

- The stability of a particular criminal formation, demonstrated by the prolonged nature of its activity, and the repeated accomplishment of similar criminal acts;

- Distribution of the roles between the members of the organization both along a vertical line (isolation of the leading component) and along a horizontal (criminal specialization) one;

- A hierarchic structure, including, as a minimum, one person, who leads the organization's activities;

- The concentration of efforts towards specific forms of criminal activity (the larger the organization, the wider the circle of such forms of activity appears);

- Intent to extract as much income as possible from criminal activity within the shortest time possible;

- Presence of a system of mutual social aid for the members of the group (for example, creation of a general cashbox containing "common money"); 
- Active resistance to law-enforcement agencies via the use of corruption mechanisms, inter alia;

- Rigid internal discipline, the presence of a specific Code of Conduct and punishment for those who breach it.

Among the facultative signs, several authors note the following:

- Detachment of the leader of organization from actual criminal activity: He is not involved in committing crime, and, frequently, he also has no direct connection to the perpetrators of the crime, acting only as the ideological inspirer of criminal activity;

- Use of mechanisms to legalize ("launder") criminal proceeds;

- Selection of personnel in the organization by national or clan characters;

- Trans-border nature of activity, connection with criminal organizations in other countries;

- Usage of new technical equipment for criminal activity. ${ }^{7}$

\section{Prevalence of organized criminality}

The scale of the activity of organized criminality is extremely high, and damage from it is sizeable. The Global Trends report by the Intelligence Council of the USA states that the data available to us shows that annual proceeds from organized criminal activity can be broken down as follows: 100-300 billion dollars from the trade in narcotics; 10-12 billion dollars from the transport of toxic substances and other dangerous items; 9 billion dollars from the theft of vehicles in the USA and Europe; 7 billion dollars from the transport of illegal migrants across borders; about one billion dollars from the violation of intellectual property rights through the illegal copying of video films, computer programs and other goods. Harm from corruption is estimated to run to approximately 500 billion dollars, which is about $1 \%$ of the world's combined GNP. This damage is the consequence of slowing economic growth, decreasing foreign investments and reducing profits. For example, according to the data of the European Bank for Reconstruction and Developments, firms which carry out business in Russia spend from 4 to 8 percent of their annual turnover on bribes. ${ }^{8}$

\section{Transnational Criminal Organizations}

Organized criminal groups have always had international contacts; however, these contacts were irregular and usually short-term in nature until the midtwentieth century. This aspect only really took off after the internationalization

\footnotetext{
A.I. Dolgovaya, ed., Organized Crime, pp. 510-511.
}

8 Global Trends 2015: A Dialogue about the Future with Nongovernment Experts (Washington DC: National Intelligence Council, 2000). 
of the economy and the propagation of trade in illegal goods (narcotics, weapon, etc.) led to a significant growth in income from transborder criminal operations.

Besides passing illegal goods (first of all narcotics) across borders, the internationalization of organized criminality is connected with the tendency of criminal groups to select territories for their operations in which the systems of criminal justice act inadequately, and in which it is easy to establish operations to legalize criminal income (for example, "tax havens").

The following basic transnational criminal organizations can be listed:

- The Italian Mafia, which is a union of several criminal organizations, including the "Ndrangheta" from Calabria. ${ }^{9}$ This includes approximately 100 families, totaling between 4,000 and 5,000 members in the region of Calabria. Other estimates suggest 6,000-7,000 men; worldwide there might be some 10,000 members. ${ }^{10}$ Another branch is the "Camorra" from Naples. This consists of 111 families and totals more than 6,700 members. "Nuova Sacra Corona Unita" from Puglia consists of about 50 clans with approximately 2,000 members $^{12}$ and finally, the Mafia "Cosa Nostra" of Sicily with 25,000 members in total, and 250,000 affiliates worldwide. There are more than 3,000 members and affiliates in the United States, scattered mostly throughout the major cities in the Northeast, the Midwest, California, and the South. Their largest presence centers around New York, southern New Jersey, and Philadelphia. ${ }^{13}$

The basic source of income for the Italian Mafia is the trade in narcotics; however, it is also involved in other illegal operations. In particular, this includes the smuggling of weapons, alcohol, and tobacco, hostage-taking and so forth. In the 1990s, the influence of the Italian Mafia was somewhat reduced thanks to the coordinated efforts of Italy's law enforcement agencies; nevertheless, it remains near the top of the list of the world's most influential criminal organizations. ${ }^{14}$

- Chinese "triads" mostly operate in the territory of Hong Kong and Taiwan; in total, there are about 50 different organizations involved in this group. Depending on the estimate you take, their members total from 160 to 300 thousand people. ${ }^{15}$ Despite the rigid hierarchic structure, the components of triads directly involved in criminal operations are the part of the flexible net system, capable of changing their structure, and being tweaked to adjust to

9 "Six morts dans un règlement de comptes mafieux en Allemagne," Le Monde, August 15, 2007.

10 John Hooper, "Move over, Cosa Nostra," The Guardian, June 8, 2006.

11 The Italian Mafia, http://sungat.ru/eng/node/54.

12 Federal Bureau of Investigation, Organized Crime, https://www.fbi.gov/investigate/ organized-crime.

13 Ibid.

14 Ibid.

15 "Kriminaliät ohne Grenzen," in Atlas der Globalisierung - Die Welt von morgen, edited by Le Monde Diplomatique (TAZ, 2012), 37. 
different conditions. Triads are involved in extortion, drug trafficking, prostitution, and gambling, and are the most important suppliers of heroin into the USA.

- Japanese "yakudza" also known as "gokudō," are members of transnational organized crime syndicates originating in Japan. The Japanese police, and media by request of the police, call them "bōryokudan" ("violent groups"), while the yakuza call themselves "ninkyō dantai" ("chivalrous organizations"). It also consists of several self-contained organizations, the largest of which is Yamaguchi-gumi, which has more than 26,000 members, followed by Inagava-kay (8,600 members) and Sumiesi-kay (more than 7,000 members). These organizations fight against one another; however, they also coordinate their activities in terms of the corruption of government officials and criminalization of the economy. Besides this, they interfere in internal economic processes (the film industry, entertainment industry, professional sport, lottery, financial sphere and the real estate market are all controlled by yakudza), they smuggle sea products and steal vehicles, narcotics (including methamphetamine) and weapons. $^{16}$

- Colombian drug cartels are occupied almost exclusively by the drug trafficking business, being the primary supplier of cocaine to the global market, at around $80 \%$. Two of the most well-known cartels are based in the cities of Medellín and Cali. The Medellin cartel was founded by Pablo Escobar and the Ochoa family, and Cali's cartel by the Santacruz and Rodriguez Orejuela families. The management level of the cartels is constructed in line with rigid hierarchical diagrams, and various cells are separated out at the lower levels, each of which is involved in a specific form of criminal activity, and is not informed about the other operations in which the cartel is involved. At the end of the 1990s, operations led by the Colombian police force and law-enforcement agencies from other countries led to a significant decrease in the volume of operations carried out by cartels; however, this void has been filled by smaller criminal organizations. ${ }^{17}$

- Nigerian criminal organizations appeared at the beginning of the $1980 \mathrm{~s}$ as a result of the Nigerian economic crisis, which was connected to a drop in the price of oil. These criminal organizations specialize in drug trafficking, and also in fraudulent operations including the use of new financial instruments and extortion. As a rule, most operations are small-size, but this is compensated by their large number.

\section{Criminal Organizations in Europe}

The 2004 European Union report (and subsequent reports) on the situation in terms of organized criminality detail the fundamental international criminal organizations acting on European soil. The most dangerous of these are Albanian

16 Ibid.

17 Ibid. 
(focusing on the trade of narcotics and people, and also attempting to control criminal markets, including by forced methods) and Russian (economic crimes, extortion, illegal immigration). ${ }^{18}$

Furthermore, the report refers to the actions of other ethnic groups: the Turks (trade in narcotics and weapons, money laundering, racketeering), Nigerians (trade in narcotics and people, fraud), Moroccans (trade in narcotics and smuggling), Colombians (trade in cocaine), Chinese (illegal migration), and Vietnamese (smuggling, illegal migration, other criminal activities).

One of the most dangerous criminal groups in Europe is the Russian Mafia. It has around 160,000 members and encompasses 12,000 groups. ${ }^{19}$

According to the research paper entitled "The biggest organized crime groups in the world", the Russian organized criminal organization "Solntsevskaya Bratva" (Solntsevo being a district in Moscow) is ranked in first place. Its revenue was estimated to amount to $\$ 8.5$ billion in $2014 .^{20}$

\section{International Experience in Fighting Transnational Organized Crime}

An international understanding of the seriousness of the threat posed by narcotics trafficking, money laundering, corruption and other crimes first began in the twentieth century as the result of the realization of the increasing scale of these challenges, which go beyond the framework of individual states and have a great, and negative, influence on the sociopolitical and economic spheres, national security and individuals. The leading role in the legal regulation of the efforts of states and the international community in combating transnational organized crime belongs to the UN: in recent decades when it became obvious that states' ability to resist the spread of international criminality individually did not match the scale of the crimes, the UN drew up a range of universal documents on the resistance to transnational organized crime (TOC) and the work of the global community in this regard took on a more systematic nature. The first international experience of fighting criminal challenges of an international nature was connected with the signing of intergovernmental agreements, including against the slave trade (Viennese convention of 1815), ${ }^{21}$

18 European Union Organised Crime Report 2004; European Union Organised Crime Report 2005; European Organised Crime Threat Assessment (OCTA), 2007.

19 "Kriminalität ohne Grenzen," 37.

20 Chris Matthews, "Fortune 5: The biggest organized crime groups in the world," Fortune, 14 September 2014, http://fortune.com/2014/09/14/biggest-organized-crimegroups-in-the-world.

21 Thomas Curson Hansard, The Parliamentary Debates from the Year 1803 to the Present Time, volume 32, 1 February to 6 March 1816 (London: T. C. Hansard, 1816), 200-201. 
the propagation of pornography (Parisian convention of 1910), ${ }^{22}$ and the forgery of monetary terms (convention of 1929). ${ }^{23}$

At the beginning of the twentieth century, the international nature of many crimes rendered it impossible for them to fall under the scope of one state alone, and this emergent situation necessitated international collaboration. The first Conference for the Unification of Criminal Law took place in Warsaw in 1927 and dealt with a number of crimes of an international nature, such as piracy, the slave trade, narcotics trafficking, the trade of pornographic materials, and the forgery of monetary terms. ${ }^{24} \mathrm{~A}$ number of legal statutes were developed to combat international crime, which are reflected in various legal documents, namely: the 2005 Nuclear Terrorism Convention, ${ }^{25}$ the 2000 UN Convention against Transnational Organized Crime, ${ }^{26}$ the 2003 UN Convention against Corruption, ${ }^{27}$ the 1988 UN Convention against Illicit Traffic in Narcotic Drugs and Psychotropic Substances, ${ }^{28}$ the 1990 Council of Europe Convention on Laundering, Search, Seizure and Confiscation of the Proceeds from Crime and on the Financing of Terrorism. ${ }^{29}$

The regulatory framework of the Council of Europe includes nine conventions pertaining to the fight against international crime. Among them are the 1998 European Convention on the Compensation of Victims of Violent Crimes, ${ }^{30}$ and the additional protocol to the 2003 Convention on Cybercrime,

22 "Russian court bans online porn, citing conventions from 1910 and 1923," Meduza, April 13, 2015, https://meduza.io/en/news/2015/04/13/russian-court-bans-onlineporn-citing-conventions-from-1910-and-1923.

23 "Counterfeiting," Encyclopedia Britannica Online, http://www.britannica.com/topic/ counterfeiting.

24 Daniel Marc Segesser and Myriam Gessler, "Raphael Lemkin and the international debate on the punishment of war crimes (1919-1948)," Journal of Genocide Research 7, no. 4 (2005): 453-468.

United Nations, International Convention for the Suppression of Acts of Nuclear Terrorism, September 14, 2005, http://www.un.org/en/sc/ctc/docs/conventions/ Conv13.pdf.

26 United Nations Office on Drugs and Crime, United Nations Convention against Transnational Organized Crime and the Protocols Thereto, https://www.unodc.org/ unodc/treaties/CTOC.

27 United Nations Office on Drugs and Crime, United Nations Convention against Corruption (Vienna: Vienna International Center, 2004), https://www.unodc.org/ documents/brussels/UN_Convention_Against_Corruption.pdf.

28 International Drug Control Conventions, https://www.unodc.org/unodc/en/ commissions/CND/conventions.html.

29 "Details of Treaty No.141," Convention on Laundering, Search, Seizure and Confiscation of the Proceeds from Crime, http://www.coe.int/en/web/conventions/full-list//conventions/treaty/141.

30 https://rm.coe.int/CoERMPublicCommonSearchServices/DisplayDCTMContent? documentld=0900001680079751. 
among others. ${ }^{31}$ Furthermore, as a rule, many international agreements contain provisions relating to collaboration with one another in countering international criminality.

With regard to the European Union, it is important to discuss the EU's solidarity clause, Article 222 of the Lisbon Treaty (TFEU). It requires EU member states to provide mutual assistance and fight terrorism together, which encompasses the prevention of terrorism. ${ }^{32}$

Multilateral international legal documents regulate the various forms of cooperation between states and international organizations surrounding the legal issues related to combating crime. Usually, collaboration is assumed on the basis of mutual legal assistance in the sphere of the exchange of information, in conducting investigations, searching out criminals, legal proceedings, seizure of property and so forth. In parallel, and in terms of this type of collaboration in the fight against transnational organized crime, different agreements have been achieved at a regional level and on a bilateral basis. The diversification of the spectrum of criminal threats at an international level and the heightened level of activity in terms of opposing them after the end of the Cold War has focused attention on the problem of fighting transnational organized criminality. The UN has assumed the coordinating role in the fight against these criminal challenges of the post-Thaw period.

Since the beginning of its existence, the UN has been involved in the problems of preventing and suppressing crime: a number of international conventions have been adopted under the aegis of the UN. The UN General Assembly also regularly considers resolutions including provisions regarding the combating of various type of crime of an international nature. Since 1955, the UN Crime Congress has been held every five years. The 11th UN Congress on Crime Prevention and Criminal Justice took place in Bangkok in April 2005. The outcome of this conference led to the development of the Bangkok Declaration: "Synergies and Responses: Strategic Alliances in Crime Prevention and Criminal Justice." 33

At the beginning of the 1990s, a number of major steps were taken within the UN framework to increase the effectiveness of the coordination of member states in the fight against TOC. In 1990, the UN General Assembly approved the model standard agreements (in the spheres of criminal justice, extradition, etc.) and the UN program on crime prevention and criminal justice was adopted in

31 Council of Europe Parliamentary Assembly, Recommendation 2077, "Increasing cooperation against cyberterrorism and other large-scale attacks on the Internet," October 15, 2015, https://rm.coe.int/CoERMPublicCommonSearchServices/Display DCTMContent?documentld=09000016804901b5.

32 Roderick Parkes, Migrations and terrorism: new frontier for European solidarity (Paris: European Union Institute for Security Studies, 2015).

33 Eleventh United Nations Congress on Crime Prevention and Criminal Justice, Bangkok, April 18-25, 2005, www.un.org/events/11thcongress/infoparticipants.pdf. 
1991. ${ }^{34}$ The basic purpose of the program is organizing assistance to member nations with regard to crime prevention and criminal justice.

The Commission on Crime Prevention and Criminal Justice was founded in 1991 as the functional commission of the UN Economic and Social Council after replacing the previous Committee on Crime Prevention and Control, founded in $1971 .^{35}$ The commission seats 40 member states, including nations from Africa (12 places), Asia (9 places), Eastern Europe (4 places), Latin America and the Caribbean (8 places), Western Europe and other states (7 places). A state is a member of the commission for 3 years.

The World Ministerial Conference on Organized Transnational Crime took place in Naples in November $1994 .{ }^{36} 142$ countries sent participants to the conference. The outcome of the conference led to the UN General Assembly adopting the Global Action Plan against Transnational Organized Crime. In 1997, the sixth session of the Commission on Crime Prevention and Criminal Justice established a working group to examine the performance of the Naples Declaration. Deliberating on the definition of organized crime became a central question in the framework of the working group: a compromise version listed the key elements that characterize organized crime, namely the presence of organization, a constant nature to its activities, the division of labor within the group, violence and deference, a hierarchy, a tendency towards obtaining profits, influence on society, media control and contact to political structures. In 1998, the Commission created an ad hoc intergovernmental committee, open to all states, including non-UN states, to develop the text of a convention on the resistance to transnational crime. As part of the committee's operations, an important role was played by individual states, which focused most of their attention on the problems with which they came into direct contact. In particular, Austria and Italy focused on illegal immigration, Argentina on child trafficking, and Japan and Canada proposed the inclusion of new tools in the fight against the illegal production of and trade in firearms.

The signing of the UN Convention against Transnational Organized Crime in 2000 , along with three associated protocols, can be seen as a watershed moment in the fight against organized crime within the UN. The UN Convention against Transnational Organized Crime focuses on crimes of a transnational nature and carried out by organized criminal groups. Organized crime is understood as reflecting the characteristics of organized criminal groups, and the severity of the violence perpetrated by them. The Convention defines an

34 United Nations Office of Drugs and Crime, Compendium of United Nations standards and norms in crime prevention and criminal justice (Vienna: Vienna International Center, 1991).

35 Luc Reydams, Jan Wouters, and Cedric Ryngaert, eds., International Prosecutors (Oxford: Oxford University Press, 2012), 169.

36 Travaux Préparatoires of the negotiations for the elaboration of the United Nations Convention against Transnational Organized Crime and the Protocols thereto, https://www.unodc.org/pdf/ctoccop_2006/04-60074_ebook-e.pdf. 
organized criminal group as "the structurally designed group in composition of three or more persons, that exists during the specific period of time and acting in concord with the purpose of committing of one or several serious crime or crimes, acknowledged as the same in accordance with the present convention, in order to obtain, directly or indirectly, financial or another material benefit" (article 2). The transnational nature of crime can be shown in a host of ways (article 3, item 2):

1. (Crime) is perpetrated in more than one state;

2. It is perpetrated in one state, but the key elements in its preparation, planning, management or control occur in another state;

3. It is perpetrated in one state, but with the participation of an organized criminal group that is involved in criminal activity in more than one state; or

4. It is perpetrated in one state, but its main consequences are felt in another state.

The text of the Convention does not mention the definition of organized crime (transnational organized crime). However, the UN's definition mentions characteristics of TOC as including its international character, the size of criminal groups and the prolonged nature of their activity. To the list of unlawful actions are added: participation in organized criminal groups (article 5), the laundering of criminal proceeds (art. 6), corruption (art. 8), and perversion of the cause of justice (art. 23). The additional protocols to the convention describe in more details the criminal nature of human trafficking, illegal immigration, and the illegal circulation of firearms. The Convention contains articles regulating matters of extradition, mutual legal aid, collaboration between law enforcement agencies, the exchange of information, and the prevention of transnational organized crime (art. 31). ${ }^{37}$ The final stage involves the adoption of the appropriate legislative, administrative and other measures for the purpose of protecting national markets against the penetration of transnational criminal groups (for example, people who are found guilty of crimes of this nature are deprived of the right to hold positions of leadership and in the judiciary, the creation of a separate national list of such people; the introduction of mechanisms of control over the procedures of trade, the delivery of subsidies and licenses, and so forth). The Conference implemented control over the fulfillment of the provisions of the Convention by evaluating participating countries on their performance and proposing additional recommendations regarding the development of international collaboration in the fight against transnational crime.

In terms of the Convention's impact, there is no requirement for participants to report on the success of its implementation as the mechanism for this is lacking: participating countries can bring their national judiciaries into line

37 Ibid. 
with the Convention's stance at their own discretion. The absence of a rigid mechanism of control is one of the deficiencies of the Convention against Transnational Organized Crime. The strongest aspect of international legislation is its universal nature. In terms of basic international legislation devoted to the fight against transnational organized crime-namely the UN Convention against Transnational Organized Crime-the participation of both developed and developing countries is tremendously important. In the course of developing the Convention's project, both developing and developed countries recognized that, when fighting organized crime, it is necessary to act on a multilateral basis, to transform national legalization into universal standards and implement them via national institutions. This acknowledgement represented a significant step forward, taking into consideration the lack of close connections between state judiciaries, along with their unwillingness to lose even the smallest aspect of their sovereignty. Also of importance is the fact that more than 125 countries participated in the convention, including some of the poorest countries in the world, which made it possible to discuss the further extension of the Convention's reach.

With regard to the interconnected nature of the world today, the basic principles of the international prevention and combat of transnational crime lie in unifying the basis of international economic collaboration, and the rules governing the behavior of particular actions in the international political and legal arenas. The global regulation of international collaboration with regard to transnational organized crime has stood the test of time. In this respect, multilateral efforts in the fight against criminal challenges on the international level form part of the complex process of the institutionalization of global regulation.

In the pursuit of universalizing the fight against transnational crime, basic tasks include the strengthening of international standards with regard to national anti-crime practices, improvement of collaboration and provision of mutual legal aid, and the coordination of the work of national law enforcement agencies.

As a result of the coordination of international efforts in the fight against transnational organized crime, one of the key achievements has been the partial ordering of profile concepts and definitions, acknowledgement by the majority of states of the existence of the threats posed by the activity of transnational criminal groups, the realization of the need for international interaction for the purpose of averting such crimes, and the pursuit of criminals and their punishment.

\section{Conclusion}

Opposition to organized crime is a much more complex problem than the fight against different individual kinds of crime, for example. Very often, organized crime has resources (human, financial, political) at its disposal to rival those of official police authorities. As a result, there are not, and cannot be, any meth- 
ods that enable significant steps to be taken against organized crime within a short period of time.

The strategic tasks of fighting organized crime, besides eliminating the basic organized criminal formations and compensating for damage caused by their activity, are the elimination of the reasons and conditions that facilitate the formation of criminal societies, complicate the involvement of new faces in criminal activity and extend the reach of the influence of crime.

The first step to be taken by law enforcement agencies in the fight against organized crime is exploiting the disconnection of these formations. Besides reacting to crimes that have been perpetrated and tracking down the offenders, another basic task is to determine the identity of the leaders of criminal formations and the crimes they have committed under law; for this, the assistance of the less dangerous members of criminal groups, considerably weakened through periods of punishment (up to the complete refusal to collaborate further with the formation), can be used in exchange for collaboration with law enforcement agencies.

Important components of measures for fighting organized crime appear to be financial control, directed towards making it difficult for operations to be carried out to legalize criminal proceeds, to use criminal capital, along with anti-corruption measures, directed toward removing from their positions those individuals working in law enforcement agencies and other state structures who contribute to organized criminal formations.

It is impossible to fight organized crime effectively without measures directed towards cleaning up society as a whole, namely, providing a legal alternative to the social services offered by crime: the state must ensure that the population can access the necessary goods and services, that unemployment remains low, that ideological and educational institutions function normally, and that lawful means are available through which to resolve social conflicts.

Which of the measures stated will prove to be most effective depends on the model according to which organized crime is organized, in conjunction with specific social conditions. Jay Albaneze defines three types of such models:

- The traditional model of the large-scale criminal conspiracy, controlled by a small group of leaders. In this instance, the most effective measures will be those directed toward the neutralization of the leaders via their arrest or by another method, which will lead to the collapse of the arrangement itself.

- The model of locally organized ethnic groups. In this case, since no centralized organization exists, the neutralization of leaders will not give the desired result, since they will be replaced by new ones. In this instance the basic steps in the fight can include financial and social aspects, in tandem with other steps directed towards the removal of cash flow from the illicit ("black") sector of the economy.

- The model of enterprise, according to which organized crime is characterized by an informal decentralized structure and appears under speci- 
fied social and economic conditions and when the legal mechanisms to guarantee the needs of the population are ineffective. For dealing with this type it is necessary, first of all, to eliminate the reasons which lead to crime, provide stability, and subsequently make social and economic processes transparent. ${ }^{38}$

Furthermore, law-enforcement agencies could attain significant results in the fight against organized crime by leveraging the special legal, material and technical bases of their activity, providing the opportunity to take the necessary measures for the prevention of the commitment of crime by organized groups, to disorganize their activity (for example, via disrupting meetings), and by preventing members of organized criminal associations apprehended by law enforcement agencies to avoid criminal responsibility.

In addition, law enforcement bodies could reach meaningful results in the struggle against organized crime, and in this regard, the special normative-legal and material-technical base of their activity, by providing a way to take the necessary measures to prevent the committing of crimes by organized groups, to disorganize their activity (for example, via disrupting criminal meetings), and by preventing members of organized criminal units who are under observation by law enforcement agencies from escaping criminal responsibility.

\section{About the author}

Nika Chitadze is Director of the Black Sea Region Geopolitical Research Center at the International Black Sea University; Associate Professor, International Black Sea University; President of the George C. Marshall Center Alumni Union, Georgia - International and Security Research Center.

E-mail:nchitadze@ibsu.edu.ge.

38 John F. Shelley, ed., Criminology (SPB Academic Publishing, 2003), p. 330. 